\title{
Stereoselective pharmacokinetics of S-salbutamol after administration of the racemate in healthy volunteers
}

\author{
B. Schmekel*, I. Rydberg ${ }^{+}$, B. Norlander ${ }^{\#}$, K.N. Sjöswärd", J. Ahlner ${ }^{\sharp \S}$, R.G.G. Andersson ${ }^{+}$
}

Stereoselective pharmacokinetics of S-salbutamol after administration of the racemate in healthy volunteers. B. Schmekel, I. Rydberg, B. Norlander, K.N. Sjöswärd, J. Ahlner, R.G.G. Andersson. (C)ERS Journals Ltd 1999.

ABSTRACT: Racemic $R, S$-salbutamol is taken to relieve bronchial constriction. Only the $R$-enantiomer has bronchodilating properties. The $S$-enantiomer has been proposed to cause in vitro bronchial hyperreactivity in guinea-pigs. Stereoselective elimination of salbutamol has been shown, with $S$-salbutamol being eliminated at a slower rate than $\boldsymbol{R}$-salbutamol. This study questioned whether rates of stereoselective elimination were similar after oral or lung delivery, and whether the $S: R$ ratio would increase after repeated inhalations in a situation resembling a common clinical use.

Eighteen healthy volunteers received single-dose racemic salbutamol as a solution instilled in the trachea during anaesthesia, as inhaled micronized powder and/or as ingested tablets. Five volunteers inhaled repeated doses of racemic salbutamol. Concentrations in plasma and urine were measured using a technique which allowed chiral separation of samples with concentrations as low as $0.1 \mathrm{ng} \cdot \mathrm{mL}^{-1}$.

The bioavailability of $S$-salbutamol was significantly higher than that of $R$-salbutamol after the different modes of administration. Stereoselective elimination was more pronounced after oral administration than after inhalation. Repeated inhalations resulted in successive increases in the $S: R$ ratio as steady state was approached.

In conclusion, the clinical consequences of increasing plasma concentrations of $S$ salbutamol need to be further assessed.

Eur Respir J 1999; 13: 1230-1235.
Depts of *Clinical Physiology, ${ }^{+}$Pharmacology, ${ }^{\#}$ Clinical Pharmacology, and Anaesthesiology, Faculty of Health, University Hospital, Linköping, Sweden. ${ }^{5}$ Dept of Forensic Chemistry, National Board of Forensic Sciences, Linköping, Sweden.

Correspondence: B. Schmekel

Institute of Medicine and Care

Dept of Clinical Physiology

University Hospital

S-58185 Linköping

Sweden

Fax: 4613145949

Keywords: Enantiomer

inhalation

oral

plasma

$R$ - and $S$-salbutamol

urine

Received: July 61998

Accepted after revision November 291998
Many drugs are formulated as racemic mixtures and it has become clear that the enantiomers may differ in their pharmacokinetic and pharmacodynamic properties. There are numerous examples of enantioselective differences [1], and single enantiomers have taken the place of racemic drugs in several areas of medicine. Salbutamol (albuterol) is a sympathomimetic drug, with potent $\beta_{2}$-adrenoceptor stimulating properties. Racemic $R, S$-salbutamol is taken for the relief of reversible bronchoconstriction and the therapeutic activity is associated with the $R$-enantiomer [2-4]. $S$-salbutamol has been demonstrated to cause increased airway responsiveness to carbachol in vitro and in vivo (in guinea-pigs) $[5,6]$. Previously it has been shown that metabolism occurs in both airways and the gastrointestinal tract by stereoselective sulphate conjugation [7]. The rate by which the bronchodilating $R$-enantiomer is sulphated greatly exceeds that of the $S$-enantiomer in vitro [8]. Unchanged $R$ - and $S$-salbutamol is excreted in urine [9]. Stereoselective elimination has been reported after administration of the racemate by oral $[3,10]$, intravenous or rectal routes [9], findings that were also supported by in vitro experiments $[11,12]$. These observations indicate a more efficient removal of the active bronchodilating $R$-enantiomer, exposing the body to higher concentrations of the $S$-enantiomer. Repeated dosing

For editorial comments see page 1223 could then lead to a greater ratio of $S: R$ salbutamol in the blood over time. Assuming that adverse effects are associated with $S$-salbutamol in humans, the clinical implication of stereoselective disposition may be of importance.

The main aim of this study was to compare the bioavailability of $R$ - and $S$-salbutamol after oral and lung administration, and to determine whether the rates of stereoselective elimination were similar with these rates of administration. To this end the racemate was administered orally, by the inhaled route or by endotracheal instillation. A further aim was to assess whether repeated inhalations of $R, S$-salbutamol would lead to a higher $S: R$ ratio than that observed after a single dose. A method was developed enabling the assessment of very low concentrations of nonsulphate conjugated $R$ - and $S$-salbutamol in plasma and urine.

\section{Material and methods}

\section{Subjects}

A total of 22 healthy nonsmoking volunteers (14 females and eight males), aged 22-64 yrs, participated in this study (table 1). There was a wash-out period of at least one week between the study days for those who participated in more than one experiment. Three different 
Table 1. - Demographic data of the healthy volunteers participating in this study

\begin{tabular}{lccccccc}
\hline $\begin{array}{l}\text { Subject } \\
\text { No. }\end{array}$ & $\begin{array}{c}\text { Sex } \\
\text { M/F }\end{array}$ & $\begin{array}{c}\text { Age } \\
\text { yrs }\end{array}$ & $\begin{array}{c}\text { Weight } \\
\text { kg }\end{array}$ & $\begin{array}{c}\text { Inhaled } \\
\text { dose }\end{array}$ & $\begin{array}{c}\text { Oral } \\
\text { dose }\end{array}$ & $\begin{array}{c}\text { Endo } \\
\text { dose }\end{array}$ & $\begin{array}{c}\text { Rep } \\
\text { dose }\end{array}$ \\
\hline 1 & M & 23 & 83 & + & + & - & - \\
2 & F & 22 & 65 & + & + & - & - \\
3 & F & 37 & 68 & + & - & - & - \\
4 & F & 43 & 63 & + & + & - & - \\
5 & F & 52 & 75 & + & + & - & + \\
6 & M & 64 & 73 & + & - & - & - \\
7 & F & 34 & 52 & - & + & - & - \\
8 & F & 45 & 54 & - & + & - & - \\
9 & F & 51 & 59 & - & + & - & - \\
10 & F & 37 & 63 & - & + & - & - \\
11 & F & 35 & 90 & - & - & + & - \\
12 & F & 28 & 62 & - & - & + & - \\
13 & M & 22 & 68 & - & - & + & - \\
14 & M & 36 & 95 & - & - & + & - \\
15 & M & 29 & 105 & - & - & + & - \\
16 & M & 26 & 80 & - & - & + & - \\
17 & M & 29 & 81 & - & - & + & - \\
18 & M & 24 & 82 & - & - & + & - \\
19 & F & 45 & 70 & - & - & - & + \\
20 & F & 41 & 52 & - & - & - & + \\
21 & F & 40 & 61 & - & - & - & + \\
22 & F & 41 & 67 & - & - & - & + \\
\hline
\end{tabular}

Six subjects inhaled $0.8 \mathrm{mg}$ micronized powder of $R, S$-salbutamol, eight subjects ingested a $4 \mathrm{mg}$ tablet of $R, S$-salbutamol, eight subjects had a solution of $0.2 \mathrm{mg} R, S$-salbutamol (diluted in saline) instilled into the bronchi via an endotracheal tube during general anaesthesia, and five subjects inhaled $0.8 \mathrm{mg} R$, $S$-salbutamol three times with $3 \mathrm{~h}$ intervals in between inhalations. M: male; F: female; Endo: endotracheal; Rep: repeated.

formulations of racemic salbutamol (Ventolin $\AA$; GlaxoWellcome, Uxbridge, Middlesex, UK) were administered: micronized inhalation powder (Diskhaler Ventolin $0.4 \mathrm{mg}$ ), a $4 \mathrm{mg}$ tablet of Ventolin or a solution of Ventolin (Ventolin $2 \mathrm{mg} \cdot \mathrm{mL}^{-1}$ ). Blood samples were collected from an antecubital vein to determine salbutamol enantiomers in plasma, and urine was collected at intervals of $0-6 \mathrm{~h}$ and $6-24 \mathrm{~h}$ after dosing and analysed for salbutamol enantiomers.

Eight subjects took a $4 \mathrm{mg}$ tablet of salbutamol in the morning after a regular breakfast. Blood samples were taken before and at 15, 30, 45, 60, 90, 120, 180, 240 and 360 min after administration.

Eight patients were subjected to elective orthopaedic surgery for traumatic injuries to a shoulder or knee, these patients were otherwise healthy individuals. They were fasting at least $8 \mathrm{~h}$ before anaesthesia and paracetamol was given rectally as premedication. Anaesthesia was induced with propofol (Diprivan $\mathbb{R}$; Zeneca, Alderley, UK) and tracheal intubation was carried out in succinylcholineapnoea. Anaesthesia was maintained with desflurane (Suprane $\mathrm{R}$; Pharmacia \& Upjohn, Stockholm, Sweden) in $\mathrm{O}_{2} /$ $\mathrm{N}_{2} \mathrm{O}$, and opioid-anaesthetic (Leptanal $\AA$; Janssen Cilag, Beerse, Belgium) was given during the perioperative period when needed. The $R, S$-salbutamol aerosol was given after a steady-state level of general anaesthesia was reached. One millilitre of a solution containing $0.2 \mathrm{mg}$ salbutamol in sterile $0.9 \%$ saline was administered via an aerosol-producing $0.2 \mathrm{~mm}$ spray-catheter (PW6p1; Olym- pus, Tokyo, Japan) inserted via the endotracheal tube and ending $1 \mathrm{~cm}$ below the tip of the tube. This particular dose was chosen based upon previous reports that $<20 \%$ of an inhaled dose reaches the bronchi [13]. When $0.1 \mathrm{mg}$ of the aerosol was instilled (carried out on two subjects who are not reported in this study) this resulted in plasma concentrations below the detection limit. The dose was therefore doubled which resulted in detectable plasma concentrations. Blood samples were collected before and at 5, 8, 11, $15,30,45,60,90,120,180$ and $240 \mathrm{~min}$ after the salbutamol aerosol was instilled. Urine was not collected in this set of experiments.

Six subjects inhaled $0.8 \mathrm{mg}$ salbutamol powder and blood samples were taken before and at 3, 6, 9, 15, 30, 45, $60,90,120,180,240$ and $360 \mathrm{~min}$ after inhalation.

Five healthy subjects inhaled two doses of $0.4 \mathrm{mg}$ salbutamol powder three times and the inhalations were performed at 3-h intervals. Blood samples, to analyse enantiomers, were collected $3 \mathrm{~h}$ after the preceding inhalation and immediately before the next dose of salbutamol. The patients had regular meals, performed their normal activities during the day and urine was not collected.

The study was approved by the Ethics Research Committee, Faculty of Health, University of Linköping, Sweden.

\section{Assay of R- and S-salbutamol}

Blood samples were collected in $7 \mathrm{~mL}$ heparinized glass tubes (Vacutainer, Becton Dickinson and Co., Rutherford, NJ, USA), and plasma was separated by centrifugation $(1,000 \times g$ for $10 \mathrm{~min})$ within 30 minutes after collection and stored in plastic tubes at $-70^{\circ} \mathrm{C}$. Urine samples $(0-6 \mathrm{~h}$ and 6-24 h after administration) were stored at $-70^{\circ} \mathrm{C}$ until analysis. The isolation of salbutamol from plasma and urine was carried out with solid phase extraction on ISOLUTE C2 (EC) columns (100 mg) (International Sorbent Technology Ltd, Hengoed, Mid Glamorgan, UK). The cartridges were preconditioned with $1 \mathrm{~mL}$ of methanol and 1 $\mathrm{mL}$ of deionized water. After preconditioning, plasma or urine samples $(1 \mathrm{~mL})$ were applied to the cartridges by vacuum suction. Standard salbutamol was dissolved in deionized water and diluted in drug-free plasma $(0.2-16$ $\left.\mathrm{ng} \cdot \mathrm{mL}^{-1}\right)$ or urine $\left(10-500 \mathrm{ng} \cdot \mathrm{mL}^{-1}\right)$. After drying, the cartridges were washed with $1 \mathrm{~mL} 0.025 \mathrm{M}$ phosphate buffer ( $\mathrm{pH} 7.3), 1 \mathrm{~mL}$ deionized water and $1 \mathrm{~mL}$ acetonitrile. Another drying procedure was performed before salbutamol was eluted with $2 \mathrm{~mL}$ methanol. The eluate was evaporated to dryness using nitrogen at $50^{\circ} \mathrm{C}$. The samples were dissolved in hexane, 1,2-dichloromethane and methanol (50:45:5) for chromatography. Plasma samples were dissolved in $80 \mu \mathrm{L}$ of which $50 \mu \mathrm{L}$ was injected for chromatography.

The chromatography was performed using a procedure which has been modified from methods previously described [9, 14]. A Chirex $3022250 \times 2.0 \mathrm{~mm}$ column (Phenomenex, Torrence, CA, USA) was used for chiral separation. During chromatography a thermostat regulated the temperature of the column to a constant $20^{\circ} \mathrm{C}$ The mobile phase consisted of hexane, 1,2-dichloromethane, methanol and trifluoroacetic acid (56.8\%, 35.0\%, 8.0\% and $0.25 \%$ ) and was degassed by sonication. The flow 
rate of the mobile phase was $0.25 \mathrm{~mL} \cdot \mathrm{min}^{-1}$, the excitation and emission wavelengths of the fluorescence detector were set at 230 and $310 \mathrm{~nm}$, respectively.

The following chemicals were used: $R$ - and $S$-salbutamol base (Sepracor Inc, Marlborough, MA, USA), Ventolin, salbutamol sulphate (GlaxoWellcome), n-hexane 95\% high performance liquid chromatography (HPLC) grade, dichloromethane HPLC grade, methanol Spectroscan, HPLC grade acetonitrile, (LAB-SCAN, Analytical Sciences, Dublin, Ireland), trifluoroacetic acid (Sigma Chemical Co., St Louis, MO, USA), potassium dihydrogen phosphate, and disodiumhydrogenphosphate-2-hydrate (Merck/Kebo, Stockholm, Sweden).

The $S$-salbutamol and $R$-salbutamol enantiomers were separated $100 \%$ at baseline, with retention time $\sim 14$ and $16 \mathrm{~min}$, respectively. The limit of detection was $0.1 \mathrm{ng} \cdot \mathrm{mL}^{-1}$ for each enantiomer, with a signal:noise ratio 3:1. The precision of the method was measured at three different levels in the urine standard curve, by analysing five samples from each concentration. The day-to-day variation for each enantiomer in the urine standard curve was $1.4 \%$ at $125 \mathrm{ng} \cdot \mathrm{mL}^{-1}, 7.7 \%$ at $25 \mathrm{ng} \cdot \mathrm{mL}^{-1}$ and $10 \%$ at $5 \mathrm{ng} \cdot \mathrm{mL}^{-1}$. The coefficient of correlation varied between 0.9986 and 0.9996 . The same procedure was used with plasma standards, analysing 6-7 samples at each concentration, and the day-to-day variation for each enantiomer was $3.5 \%$ at 3 $\mathrm{ng} \cdot \mathrm{mL}^{-1}, 18 \%$ at $0.25 \mathrm{ng} \cdot \mathrm{mL}^{-1}$ and $36 \%$ at $0.1 \mathrm{ng} \cdot \mathrm{mL}^{-1}$. The coefficient of correlation for plasma analyses varied between 0.9959 and 0.9992 .

\section{Statistical methods}

Individual $R$ - and $S$-salbutamol plasma concentration curves versus time were used to obtain the maximum plasma concentration $(C \max )$ and the time from administration to time of maximum plasma concentration ( $t$ max). The area under the curve (AUC) for the separate enantiomer plasma concentrations were calculated applying the trapezoidal rule, for the time from inhalation or ingestion until $6 \mathrm{~h}$ after the administrations. AUCs were also calculated for $4 \mathrm{~h}$ after administration to the trachea via an endotracheal tube. A mono-exponential elimination equation was applied to individual plasma concentration data recorded from $t$ max to the end of the recording after the racemate was inhaled. Elimination constants $(\tau)$ of $S$ - and $\mathrm{R}$-salbutamol plasma concentrations were calculated by applying the elimination equation $\left.\left(\mathrm{A} \times \mathrm{C}^{-\left(\mathrm{x}-\mathrm{x}_{0}\right.}\right) / \tau\right)$; $\mathrm{A}$ is the plasma concentration, $\mathrm{C}$ is a constant, $\mathrm{x}$ and $\mathrm{x}_{0}$ refer to time intervals where $x_{0}$ indicates the time at the start of elimination, and $\tau$ is the elimination (or time) constant which is associated with the plasma half-life of the compound. A commercially available computer program (Origin 2.8, MicroCal Software Inc., Northampton, MA, USA) was used in order to calculate plasma elimination constants. The quantities of unchanged drug excreted into the urine for the time periods $0-6 \mathrm{~h}$ and $6-24 \mathrm{~h}$ after ingestion or inhalation were added together to give a cumulative amount excreted over $24 \mathrm{~h}$. Mean values and a 95\% confidence interval (CI) were used to describe data, unless otherwise indicated. Student's t-test of paired or unpaired data or a one-way analysis of variance (ANOVA) test were used to compare the data, and the level of significance was set at a pvalue $=0.05$.

\section{Results}

\section{Oral administration: tablet}

The profiles of plasma concentration to time curves for $S$-salbutamol and $R$-salbutamol after a single oral dose of $R, S$-salbutamol are shown in figure 1a. Plasma AUC and $C$ max were significantly higher for $S$-salbutamol than for $R$-salbutamol $(\mathrm{p}<0.001$ and $\mathrm{p}<0.001$, respectively, table
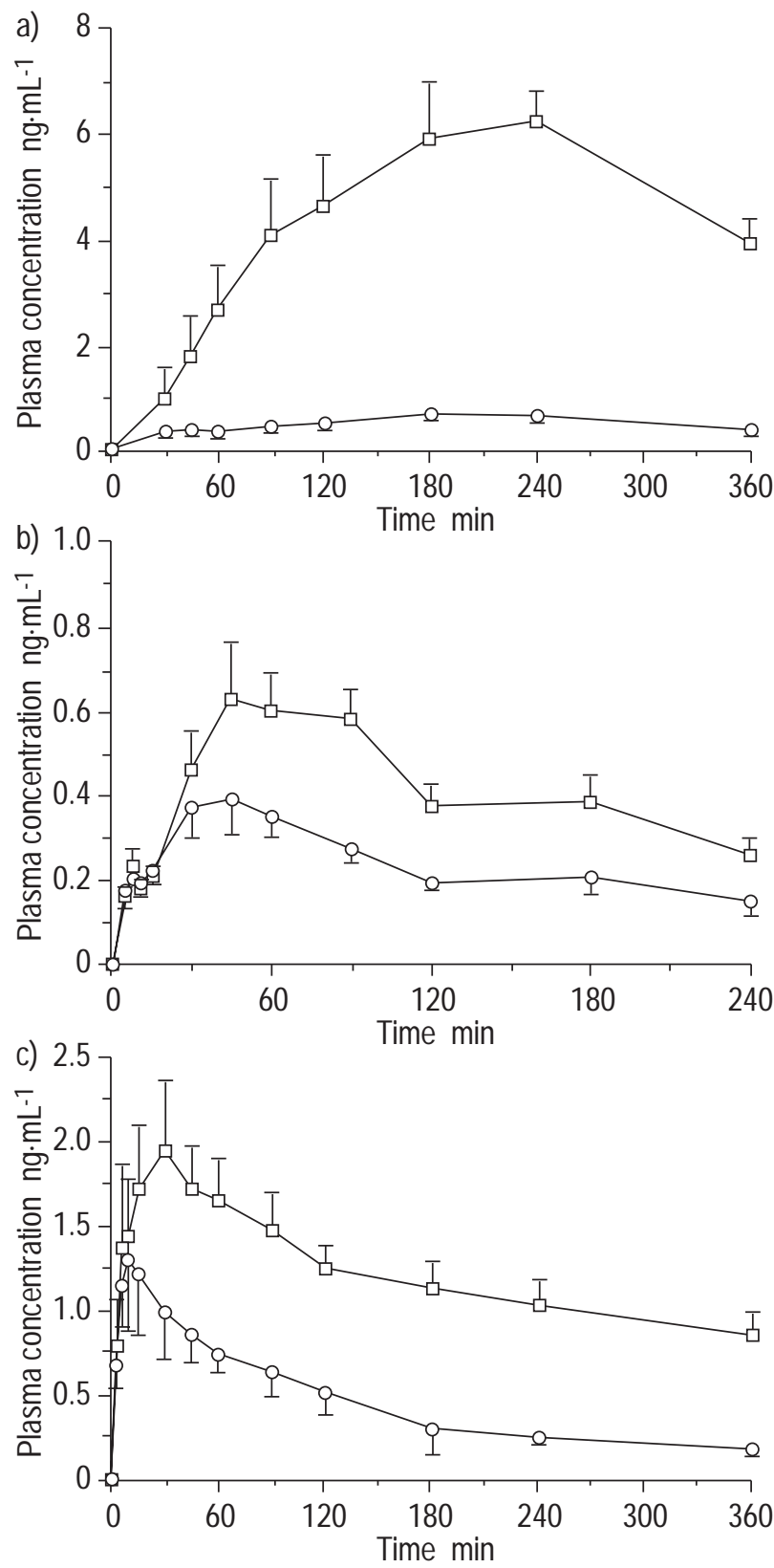

Fig. 1. - a) $S$ - and $R$-salbutamol plasma concentrations after an oral dose of $4 \mathrm{mg}$ of $R, S$-salbutamol in eight healthy volunteers followed for $6 \mathrm{~h}$. Data were obtained from $4-8$ subjects. b) $S$ - and $R$-salbutamol plasma concentrations after an endotracheal aerosol dose of $0.2 \mathrm{mg}$ of $R, S$-salbutamol in eight healthy volunteers followed for $4 \mathrm{~h}$. Data were obtained from 6-8 subjects. c) $S$ - and $R$-salbutamol plasma concentrations after inhalations of $0.8 \mathrm{mg}$ of $R, S$-salbutamol in six healthy volunteers followed for $6 \mathrm{~h}$. Data were obtained from 3-6 subjects. For further information see text. Data are presented as means \pm SEM. $\square: S$-salbutamol; $\bigcirc: R$-salbutamol. 
Table 2. - Pharmacokinetic data obtained in plasma or urine after administration of either a $4 \mathrm{mg}$ tablet, $0.2 \mathrm{mg}$ solution or $0.8 \mathrm{mg}$ micronized inhalation powder of racemic salbutamol to healthy volunteers

\begin{tabular}{|c|c|c|}
\hline & $S$-salbutamol & $R$-salbutamol \\
\hline \multicolumn{3}{|c|}{ Oral administration $4 \mathrm{mg} R, S$-salbutamol (tablet) } \\
\hline \multicolumn{3}{|c|}{ Plasma } \\
\hline AUC $0-6 \mathrm{~h} \mathrm{ng} \cdot \mathrm{mL}^{-1} \cdot \mathrm{h}^{-1}$ & $26.5(18.4-34.6)$ & $3.2(1.7-4.6)^{* * *}$ \\
\hline$C \max \mathrm{ng} \cdot \mathrm{mL}^{-1}$ & $7.2(5.2-9.1)$ & $1.0(0.7-1.2)^{* * *}$ \\
\hline tmax min & $206(161-252)$ & $150(78-222)$ \\
\hline \multicolumn{3}{|l|}{ Urine } \\
\hline Urine $0-6 \mathrm{~h} \mu \mathrm{g}$ & $200.8(80.4-321.2)$ & $46.7(25.0-68.4)^{* *}$ \\
\hline Urine $6-24 \mathrm{~h} \mu \mathrm{g}$ & $318.3(196.3-440.2)$ & $59.9(33.8-86.0)^{* * *}$ \\
\hline Urine $0-24 \mathrm{~h} \mathrm{\mu g}$ & $519.1(278.4-759.8)$ & $106.6(62.1-151.2)^{* *}$ \\
\hline \multicolumn{3}{|c|}{ Endotracheal administration $0.2 \mathrm{mg} R, S$-salbutamol (solution) } \\
\hline \multicolumn{3}{|c|}{ Plasma } \\
\hline AUC0-6 h ng $\cdot \mathrm{mL}^{-1} \cdot \mathrm{h}^{-1}$ & $1.6(1.2-2.0)$ & $0.7(0.4-1.0)^{* *}$ \\
\hline $\mathrm{Cmax}_{\mathrm{ng} \cdot \mathrm{mL}^{-1}}$ & $0.7(0.4-1.0)$ & $0.4(0.3-0.6)^{* *}$ \\
\hline$t \max \min$ & $68(46-89)$ & $53(36-69) *$ \\
\hline \multicolumn{3}{|c|}{ Inhaled administration $0.8 \mathrm{mg} R, S$-salbutamol } \\
\hline \multicolumn{3}{|c|}{ Plasma } \\
\hline $\mathrm{AUC} 0-6 \mathrm{~h} \mathrm{ng} \cdot \mathrm{mL}^{-1} \cdot \mathrm{h}^{-1}$ & $7.0(5.5-8.5)$ & $1.9(1.5-2.3)^{* * *}$ \\
\hline$C_{\max } \mathrm{ng} \cdot \mathrm{mL}^{-1}$ & $2.0(1.5-2.5)$ & $1.2(0.9-1.6)^{* * *}$ \\
\hline$t \max \min$ & $38(25-50)$ & $21(13-30)^{*}$ \\
\hline \multicolumn{3}{|l|}{ Urine } \\
\hline Urine $0-6 \mathrm{~h} \mu \mathrm{g}$ & $73.0(50.8-95.2)$ & $40.2(28.9-51.5)^{* * *}$ \\
\hline Urine $6-24 \mathrm{~h} \mu \mathrm{g}$ & $60.9(41.0-80.8)$ & $18.0(9.8-26.2)^{* * *}$ \\
\hline Urine $0-24 \mathrm{~h} \mu \mathrm{g}$ & $97.5(60.7-134.3)$ & $42.7(20.8-64.6)^{* * *}$ \\
\hline
\end{tabular}

Data presented as means with $95 \%$ confidence intervals in parentheses. AUC: area under the curve; $C$ max: maximum plasma concentration; $t$ max: time of $C$ max. ${ }^{*}: \mathrm{p}<0.05 ;{ }^{* *}: \mathrm{p}<0.01 ; * * * \mathrm{p}<0.001$, significantly different to $S$-salbutamol.

2). Furthermore, differences between plasma enantiomer levels tended to increase with time (fig. 2) leading to an increasing $S: R$ ratio in plasma. The mean $(95 \% \mathrm{CI}) S: R$ ratio was $2.5(0.9-4.1)(\mathrm{n}=4$, concentrations of $R$-salbutamol were not detectable in four subjects) 30 min after the racemate was ingested and was $8.0(5.1-10.8)(n=7$, not detectable in one subject) $3 \mathrm{~h}$ after ingestion.

The total amount of unchanged $S$-salbutamol in urine, collected $0-24 \mathrm{~h}$ after ingestion, was significantly higher than that of $R$-salbutamol ( $\mathrm{p}<0.01)$, as well as when measured in two separate time periods, $0-6 \mathrm{~h}$ and $6-24 \mathrm{~h}$ after the tablet was ingested $(p<0.01$ and $p<0.001$, respectively,

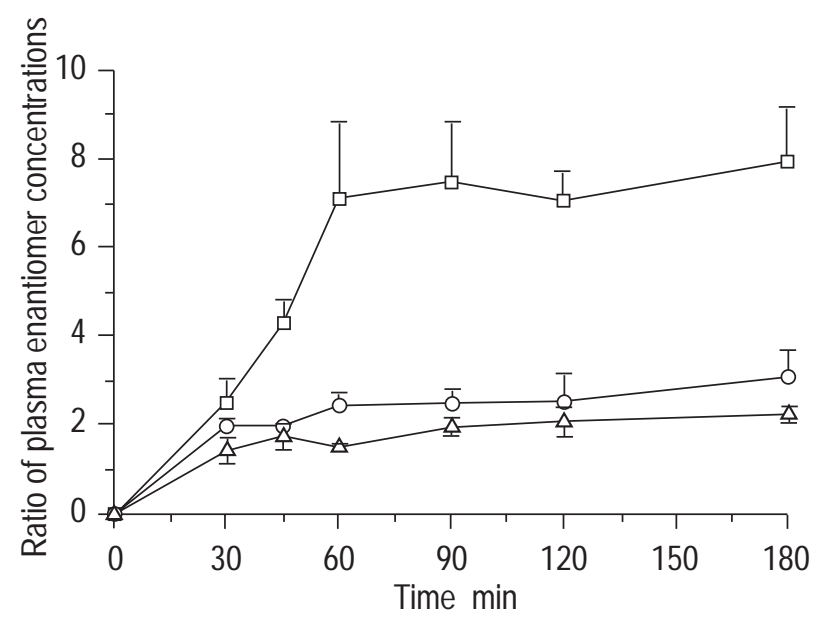

Fig. 2. - The ratio of $S$-salbutamol: $R$-salbutamol plasma concentrations obtained after an oral dose of $4 \mathrm{mg}$ of $R, S$-salbutamol $(\square$; $\mathrm{n}=8)$, inhalation of $0.8 \mathrm{mg} R, S$-salbutamol $(\bigcirc ; \mathrm{n}=6)$ or endotracheal administration of $0.2 \mathrm{mg} R, S$-salbutamol $(\triangle ; \mathrm{n}=8)$. Data are presented as mean \pm SEM. Owing to undetectable plasma concentrations of $R$-salbutamol, data from 3-8 subjects are presented, see text for further information. table 2). The ratio of unchanged $S$-salbutamol to $R$-salbutamol in urine increased with time from 4.1 (2.9-5.2) during the $0-6 \mathrm{~h}$ sampling periods to $5.9(4.2-7.7)(\mathrm{p}=$ $0.03, \mathrm{n}=8$ ) during $6-24 \mathrm{~h}$ after administration.

\section{Endotracheal administration: aerosol}

The profiles of plasma concentration to time curves for $S$-salbutamol and $R$-salbutamol after endotracheal administration of $0.2 \mathrm{mg} R, S$-salbutamol are shown in figure $1 \mathrm{~b}$. Plasma AUC 0-4 h, $C \max$ and $t_{\max }$ were significantly higher for $S$-salbutamol than for $R$-salbutamol ( $<<0.01$, $\mathrm{p}<0.01$ and $\mathrm{p}<0.05$, respectively, table 2). The mean $(95 \%$ CI) $S: R$ ratio was $1.4(0.7-2.2) 30 \mathrm{~min}$ after administration to the airways and $2.3(1.8-2.8)(n=6$, concentrations of $R$-salbutamol were not detectable in two subjects) $3 \mathrm{~h}$ after administration ( $p>0.05$, fig. 2 ). When comparing the plasma ratios of $S$ - and $R$-enantiomer levels, these were smaller after endotracheal administration than after oral administration ( $p=0.012$, one-way ANOVA).

Despite the fact that the total dose taken orally was 20times higher than the one administered to the bronchi via aerosol, the mean $C \max$ of $R$-salbutamol was 2.5-times larger and $C$ max of $S$-salbutamol was $\sim 10$-times larger after ingestion than after endotracheal administration.

\section{Inhaled administration: micronized inhalation powder}

The profiles of plasma concentration to time curves for $S$-salbutamol and $R$-salbutamol after inhalation of 0.8 $\mathrm{mg} R, S$-salbutamol are shown in figure 1c. Plasma AUC, $C \max$ and $t$ max were significantly higher for $S$-salbutamol than for $R$-salbutamol $(\mathrm{p}<0.001, \mathrm{p}<0.001$ and $\mathrm{p}<0.05$, respectively, table 2 ). The elimination constants were 
significantly higher for $S$-salbutamol than for $R$-salbutamol (110.7 (52.5-168.9) and 34.5 (20.8-48.2), respectively, $\mathrm{p}<0.01)$ indicating that $R$-salbutamol is metabolized faster than $S$-salbutamol. The mean $S: R$ ratio in plasma was $2.0(1.5-2.4)(\mathrm{n}=6) 30 \mathrm{~min}$ after inhalation and was $3.1 \quad(0.4-5.7) \quad(n=3$, R-salbutamol plasma concentrations were not detectable in three subjects) 3 $\mathrm{h}$ after inhalation (fig. 2).

The amount of unchanged $S$-salbutamol was significantly higher than that of $R$-salbutamol in urine measured $0-24 \mathrm{~h}(\mathrm{p}<0.001)$, as well as in the two time periods $0-6 \mathrm{~h}$ and $6-24 \mathrm{~h}$ after inhalation $(\mathrm{p}<0.001$ and $\mathrm{p}<0.001$, respectively, table 2 ). The ratio of unchanged $S$-salbutamol to $R$-salbutamol in urine increased with time from 1.9 (1.5-2.3) to $4.4(3.2-5.6)$ during the sampling periods $0-$ $6 \mathrm{~h}$ and $6-24 \mathrm{~h}$ after administration $(\mathrm{p}<0.001, \mathrm{n}=6)$.

The nominal dose inhaled was four-times larger than that given to the bronchi by endotracheal instillation, but $C$ max for $R$-salbutamol, recorded after inhalation was threetimes as high. Also, $C \max$ of $S$-salbutamol appeared in plasma at an earlier stage after inhalation than after bronchial instillation ( $\mathrm{p}=0.04$, ANOVA). The differences in $C_{\max }$ of $S$-salbutamol recorded after the three different types of administration and/or formulation were greater $(\mathrm{p}<0.05$, all comparisons) than the differences in $R$-salbutamol concentration ( $\mathrm{p}>0.05$, all comparisons).

\section{Repeated inhalations}

Plasma concentrations of $S$-salbutamol were significantly higher $3 \mathrm{~h}$ after the last administration compared to $3 \mathrm{~h}$ after the first administration $\left(2.1(1.0-3.3) \mathrm{ng} \cdot \mathrm{mL}^{-1}\right.$ versus $0.8(0.1-1.5) \mathrm{ng} \cdot \mathrm{mL}^{-1}, \mathrm{p}<0.01$, fig. 3) There was no significant difference between $R$-salbutamol plasma concentration measured $3 \mathrm{~h}$ after the last and first administrations $\left(0.4(0-0.8) \mathrm{ng} \cdot \mathrm{mL}^{-1}\right.$ versus $0.1(0-0.2) \mathrm{ng} \cdot \mathrm{mL}^{-1}$, $\mathrm{p}>0.05$, fig. 3 ).

\section{Discussion}

Based on the differences in the values of plasma AUCs, total body exposure to $S$-salbutamol was significantly

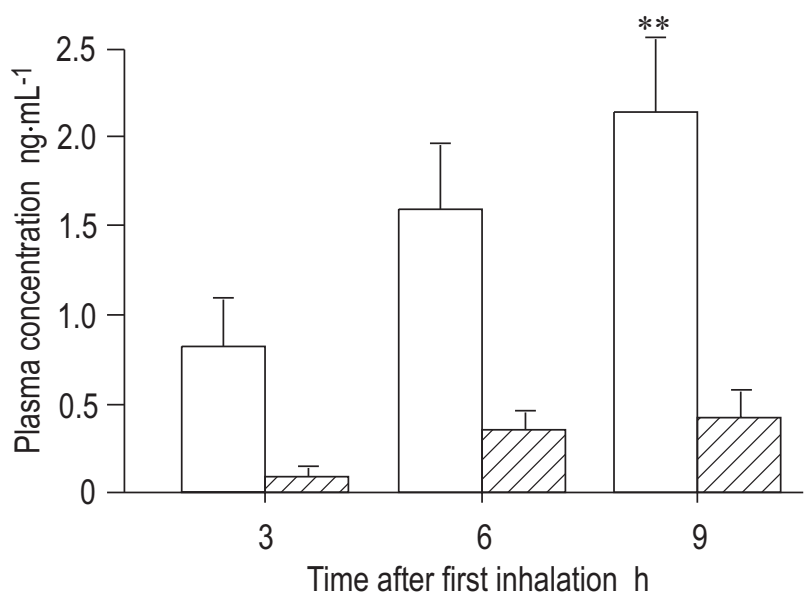

Fig. 3. $-S$ - and $R$-salbutamol plasma concentrations after three repeated inhalations of $0.8 \mathrm{mg}$ of $R, S$-salbutamol in five healthy volunteers every $3 \mathrm{~h}$. Data are presented as mean \pm SEM. $\square: S$-salbutamol; $\mathbb{Z}: R$ salbutamol. $* *: p<0.01$, significant differences between concentrations of $S$-salbutamol measured $3 \mathrm{~h}$ after the first and last inhalation. higher than that of $R$-salbutamol after inhalation, ingestion as well as after endotracheal administration of $R, S$ salbutamol. The half-life of S-salbutamol, as indicated by elimination constants, was significantly longer than that of $\mathrm{R}$-salbutamol after the racemate was inhaled. Differences in elimination rates after repeated inhalation of $R, S$ salbutamol may cause the component that is metabolized at a slower rate, i.e. $S$-salbutamol, to successively increase in the blood pool. If dose intervals are kept long enough to allow the elimination of $R$-salbutamol and short enough to allow significant $S$-salbutamol residue in plasma, successively raised levels of $S$-salbutamol in plasma might be found. The intention of this study was to mimic a feasible scenario of a patient with symptomatic asthma. Therefore, repeated inhalations and selected clinically common doses and intervals at which the racemate was inhaled were administered. In doing this, it was found that the healthy volunteers had significantly higher $S$-salbutamol plasma levels after three inhalations with an interval of 3-h in between, but this was not the case for $R$-salbutamol. It is not known whether successively increasing plasma levels also reflect the increases of $S$-salbutamol in bronchial or lung tissue in vivo. It is also not known whether higher levels of $S$-salbutamol per se, than of $R$-salbutamol, result in clinical effects. Enhanced bronchial hyperresponsiveness has been shown in guinea-pigs exposed to high levels of $S$-salbutamol in vivo [5]. Provided that human airways respond in a similar manner to $S$-salbutamol, the scenario with successively increasing $S$-salbutamol plasma levels after repeated inhalation may develop into a potentially hazardous situation. There are several reports suggesting worsening of asthma after regular treatment with $\beta_{2}$ adrenoceptors [15], and asthma instability was reported after regular treatment with salbutamol [16].

The relationship between AUCs for $S$ - and $R$-salbutamol plasma concentrations was about 8:1 after administration to the gastrointestinal tract, while it was only $\sim 2: 1$ after deposition on the bronchial mucosa via an endotracheal catheter. The concept of differential rates of metabolism at first passage by various exposed organs is also supported by a relationship between the amounts of unchanged $S$ and $R$-salbutamol in urine. The relationship between the total amount of $S$ - and $R$-salbutamol was $\sim 5: 1$ after $R, S$ salbutamol was ingested, while the corresponding relationship after inhalation was $\sim 2: 1$. Most $R$-salbutamol plasma concentrations, although well above the detection limit, were low after endotracheal administration, and a variability of the analyses from day-to-day of up to $36 \%$ in the lowest detectable concentration range, diminishes the validity of comparing data in these ranges. Taking all data into consideration, however, these results indicate that the intestinal tract is more efficient than the airways in eliminating $R$-salbutamol. The capacity of the lung to remove salbutamol from the systemic circulation is, however, not fully known. The present data do not support the assumption that the removal capacity of the lungs is comparable to that of the liver, an assumption which was based on theoretical grounds, considering the size of the organs and the presence of specific transferases responsible for elimination of the compounds considered [11].

In agreement with other data recorded, in the present conscious subjects who inhaled the racemate, it was found that the $t$ max of $S$-salbutamol was slightly higher than that of $R$-salbutamol after $R, S$-salbutamol was administered as 
an aerosol to bronchial mucosa via an endotracheal catheter during general anaesthesia (i.e. an average $1 \mathrm{~h}$ after the aerosol was instilled). The $t$ max for $S$-salbutamol, as well as for $R$-salbutamol, was found to be about twice as high after endotracheal administration as after an inhaled administration. In contrast to the findings during general anaesthesia, a tmax was already recorded within a few minutes after a canister of salbutamol metered-dose inhaler (MDI) was actuated via an intratracheal catheter in rabbits anaesthetized by halothane and ventilated with $100 \% \mathrm{O}_{2}$ [17]. It is not known whether the latter findings were influenced by dysfunction of surfactant, presumably depleted by halothane in combination with $100 \% \mathrm{O}_{2}$, or whether this was a combined effect of induced epithelial damage [18]. The delayed absorption in the present experiments may possibly have a bearing on a number of factors which might influence the airways during general anaesthesia, such as transient changes in the efficacy of the airway microvasculature and/or interference with metabolic processes by anaesthetics. To the best of the authors' knowledge, there have been no reports on the effect of general anaesthesia on the pharmacokinetics of inhaled drugs.

In conclusion, stereoselective first pass and/or systemic elimination of salbutamol is a reality, and overall removal of $S$-salbutamol is considerably slower than that of $R$ salbutamol. Elimination of $R$-salbutamol was more rapid when the racemate was administered orally than via airways. This causes much higher plasma levels of $S$-salbutamol than $R$-salbutamol, after ingestion of the racemic compound, but also after inhalation due to the fact that the bulk of an inhaled dose is swallowed and ends up in the gastrointestinal tract [13]. That successively higher plasma concentrations of $S$-salbutamol occur after repeated inhalation stresses the importance of using inhalation devices, which are efficient in delivering the dose to the pulmonary compartment. The clinical consequences of a stereoselective elimination of salbutamol are presently not known and a potentially harmful effect of high levels of the $S$-enantiomer in the absence of bronchodilating and thus protective $R$-enantiomer is an open question. However, a number of articles and reviews reporting adverse effects of regular treatment with inhaled $\beta_{2}$-adrenoceptor agonists have been published $[15,19-22]$, and the role of the $S$-enantiomer in these effects will need to be further investigated.

\section{References}

1. Islam MR, Mahdi JG, Bowen ID. Pharmacological importance of stereochemical resolution of enantiomeric drugs. Drug Safety 1997; 17: 149-165.

2. Brittain RT, Farmer JB, Marshall RJ. Some observations on the $\beta$-adrenoceptor agonist properties of the isomers of salbutamol. Br J Pharmacol 1973; 48: 144-147.

3. Boulton DW, Fawcett JP. Pharmacokinetics and pharmacodynamics of single oral doses of albuterol and its enantiomers in humans. Clin Pharmacol Ther 1997; 62: 138-144.

4. Lipworth BJ, Clark DJ, Koch P, Arbeeny C. Pharmacokinetics and extrapulmonary $\beta_{2}$ adrenoceptor activity of nebulised racemic salbutamol and its $R$ and $S$ isomers in healthy volunteers. Thorax 1997; 52: 849-852.

5. Hoshiko K, Morley J. Exacerbation of airway hyperreactivity by racemic salbutamol in sensitised guinea-pigs. Jpn J Pharmacol 1993; 63: 159-163.
6. Johansson F, Rydberg I, Åberg G, Andersson RGG. Effects of albuterol enantiomers on in vitro bronchial reactivity. Clin Rev Allergy Immunol 1996; 14: 57-64.

7. Morgan DJ. Clinical pharmacokinetics of beta-agonists. Clin Pharmacokinet 1990; 18: 270-294.

8. Boulton DW, Fawcett JP. Enantioselective disposition of salbutamol in man following oral and intravenous administration. Br J Clin Pharmacol 1996; 41: 35-40.

9. Boulton DD, Fawcett JP. Determination of salbutamol enantiomers in human plasma and urine by chiral highperformance liquid chromatography. $J$ Chromatogr $B$ Biomed Appl 1995; 672: 103-109.

10. Tan YK, Soldin SJ. Analysis of salbutamol enantiomers in human urine by chiral high-performance liquid chromatography and preliminary studies related to the stereoselective disposition kinetics in man. J Chromatogr 1987; 422: 187-195.

11. Eaton EA, Walle UK, Wilson HM, Aberg G, Walle T. Stereoselective sulphate conjugation of salbutamol by human lung and bronchial epithelial cells. Br J Clin Pharmacol 1996; 41: 201-206.

12. Walle UK, Pesulo GR, Walle T. Stereoselective sulphate conjugation of salbutamol in humans: comparison of hepatic, intestinal and platelet activity. Br J Clin Pharmacol 1993; 35: 413-418.

13. Pauwels R, Newman S, Borgström L. Airway deposition and airway effects of antiasthma drugs delivered from metered-dose inhalers. Eur Respir J 1997; 10: 2127-2138.

14. Aboul-Enein HY, Serignese V. Direct separation of albuterol enantiomers in biological fluids and pharmaceutical formulations using $\alpha_{1}$-acid glycoprotein and pirkle urea type columns. Chirality 1995; 7: 158-162.

15. Sears MR, Taylor DR. The $\beta_{2}$-agonist controversy. Observations, explanations and relationships to asthma epidemiology. Drug Safety 1994; 259-283.

16. van Essen-Zandvliet EEM, Hughes MD, Waalkens HJ, Duiverman FJ, Pocock SJ, Kerrebijn KF, and the Dutch CNSLD Study Group. Effects of 22 months of treatment with inhaled corticosteroids and/or beta-2-agonists on lung function, airway responsiveness, and symptoms in children with asthma. Am Rev Respir Dis 1992; 146: 547-554.

17. Wollmer P, Schairer W, Bos JAH, Bakker W, Krenning EP, Lachmann B. Pulmonary clearance of ${ }^{99 \mathrm{~m}}$ Tc-DTPA during halothene anaesthesia. Acta Anaesthesiol Scand 1990; 34: 572-575.

18. Spahr-Schopfer IA, Lerman J, Cutz E, Newhouse MT, Dolovich M. Proximate delivery of a large experimental dose from salbutamol MDI induces epithelial airway lesions in intubated rabbits. Am J Respir Crit Care Med 1994; 150: 790-794.

19. Sears MR, Taylor DR, Print CG. Regular inhaled betaagonist treatment in bronchial asthma. Lancet 1990; 336: 1391-1396.

20. Kraan J, Koeter GH, Mark ThW, Sluiter HJ, De Vries K. Changes in bronchial hyperreactivity induced by 4 weeks of treatment with antiasthmatic drugs in patients with allergic asthma: a comparison between budesonide and terbutaline. J Allergy Clin Immunol 1985; 76: 628-636.

21. Kerrebijn KF, van Essen-Zandvliet EEM, Neijens HJ. Effect of long-term treatment with inhaled corticosteroids and beta-agonists on the bronchial responsiveness in children with asthma. J Allergy Clin Immunol 1987; 79: 653-659.

22. Evans DW, Salome CM, King GG, Rimmer SJ, Seale JP, Woolcock AJ. Effect of regular inhaled salbutamol on airway responsiveness and airway inflammation in rhinitic non-asthmatic subjects. Thorax 1997; 52: 136-142. 